\title{
Cortés, Santiago, y Granados, Berenice (coord.) (2019), El rey que se ahogó. Relatos de Yunuén, Morelia, LANMO, 195. pp.
}

El rey que se ahogó. Relatos de Yunuén reúne un conjunto de testimonios —ricos, variados e interesantes - que fueron narrados por los habitantes de la isla de Yunuén, en Pázcuaro, Michoacán. Santiago Cortés y Berenice Granados fueron los coordinadores de este libro, financiado por un proyecto Papyme y llevado a cabo por el Laboratorio Nacional de Materiales Orales (LANMO) de la Escuela Nacional de Estudios Superiores de la UNAM, campus Morelia. Los registros orales fueron colectados entre junio de 2013 y junio de 2014 con la ayuda de 7 estudiantes de la Licenciatura en Literatura Intercultural.

El objetivo de compendiar estas historias es, en primer lugar, asir y resguardar la cosmovisión y manifestación cultural de los habitantes de Yunuén; en segundo lugar, mostrar el tesoro oral que existe en esta isla. Como en toda la literatura oral, podemos encontrar puntos de contacto y divergencia que existen entre una misma historia con diferentes variantes, como puede observarse en algunos de los textos publicados.

La obra, además, tiene un respaldo conformado por una serie de imágenes que sirven de referencia visual de la isla para que el lector pueda vislumbrar de forma específica la localidad y así enlazar los relatos con el entorno, con el ambiente lacustre, cotidiano y antiguo.

En la transcripción de los relatos recopilados se ha intentado conservar, en la medida de lo posible, sus rasgos orales; de manera adicional, se incluyen notas al pie de página que guían al lector a través del contexto en el que se desenvuelven las historias. Estas notas explican, principalmente, el idiolecto del emisor, o bien, alguna traducción de la lengua purépecha, así como la especificación de algún recurso extralingüístico, como el movimiento corporal realizado por los narradores. Estos movimientos tienen la finalidad de acentuar la somatización del territorio, es decir, mostrarnos una representación de la isla de Yunuén mediante el cuerpo de quien cuenta la historia.

Hacia el final del libro se incluye un listado de los narradores en el que se esbozan algunos aspectos de su vida: profesión, edad y algún dato curioso. Casi todos son hablantes del purépecha, y gracias a este listado podemos familiarizarnos con ellos; son personas que han preservado sus tradiciones y que mediante relatos orales expresan un imaginario coletivo, vital y vigente.

La colección de relatos fue cuidadosamente clasificada por temas. Primero, tenemos la sección denominada «Espacio». Aquí podemos encontrarnos con todas aquellas historias vinculadas con el espacio que permiten al lector no sólo situarse en el lugar, sino también, conocer, por ejemplo, el origen del nombre de la isla, del cual existen varias versiones. Justamente es de esta sección de donde se sustrae el título del libro: $E l$ rey que se ahogó, pues se cuenta que, gracias al desenlace trágico de un rey purépecha, la isla toma la forma de su cuerpo inerte en el agua. También se incluyen relatos en los que supuestamente algunos animales son responsables de haber formado ciertos lugares de la isla e historias de seres sobrenaturales que, en ciertos sitios, pueden otorgar favores a los seres humanos.

A continuación, está la segunda sección llamada «Tiempo» (en tanto que una vez establecido el espacio, es necesario determinar una temporalidad), en la cual tenemos 
historias enlazadas que van develando poco a poco el inicio del poblamiento del lugar. Algunas mencionan a entes o seres negativos que vivían en la isla; otras más nos muestran a una Yunuén vacía, cuando no había pobladores en este sitio considerado mágico y hay incluso historias sobre orígenes del cementerio.

En la tercera parte denominada «Cambio» nos encontramos con las historias que hacen referencia a la mudanza, a la transformación. Tenemos, entonces, relatos que nos muestran la evolución a través del tiempo de los lugares que conforman Yunuén: cuáles fueron las primeras casas, la llegada de la electricidad a la comunidad, la construcción de la escuela y de otros lugares.

Gracias al testimonio de algunas personas logramos saber que, a través de dos personajes, Raúl Velasco, el presentador del famoso programa televisivo Siempre en domingo, y del «tata» Lázaro Cárdenas del Río, no sólo se transformó el entorno físico al introducirse de mejoras estructurales en los hogares, sino que la vida y la perspectiva de los habitantes dieron un vuelco, y hasta es posible percibir el agradecimiento de aquellos que fueron beneficiados por tales transformaciones. En este punto, nos damos cuenta de que cada vez más nos acercamos a los sentimientos y a la vida sencilla, mágica de los isleños. Nos familiarizamos hasta lo más íntimo de cada recóndito lugar de Yunuén.

En la cuarta sección denominada «Vivir en Yunuén» aparecen los relatos que hablan de vida cotidiana en la isla, los cuales nos permite colarnos en las actividades diarias que practican sus habitantes. Conocemos un poco sobre las costumbres que podríamos considerar sencillas y menores, pero que aquí toman una gran importancia y evidencian el cambio entre una generación y otra, como la pesca misma, el recoger agua, el inicio del turismo en la isla, incluso el cortejo entre pobladores de una isla a otra. También se menciona la disminución en la población de ciertas especies de peces.

A partir de los testimonios recogidos, el lector conoce los interesantes rituales nupciales y mortuorios de Yunuén. Como siempre, en México la muerte termina transfigurándose en una celebración colorida, pero en Yunuén la festividad del Día de muertos es simplemente maravillosa. Otras historias simples y ricas nos acercan un poco más no sólo a las costumbres y tradiciones orales, también a las que están vinculadas con la gastronomía.

Por último, en la sección «Habitar el Lago» tenemos las narraciones que hablan de la forma de vivir y relacionarse con el entorno acuático, pues no podía faltar un apartado especial que hiciera referencia al vínculo que los habitantes guardan con el agua. Es posible observar que todas las narraciones tienen al lago como hilo conductor.

Los pequeños relatos que conforman esta sección nos hablan de los fenómenos físicos y sobrenaturales relacionados con el agua: remolinos, lagunas encantadas, gente caminando bajo el agua, culebras mágicas. Hay relatos que narran la existencia de «encantos», nombre con el que se identifica a los sitios que están hechizados y estas historias están desperdigados por toda la isla, incluso llegan hasta el agua que «sostiene» a Yunuén.

Finalmente, gracias al orden de estos cinco ejes temáticos importantes que conforman la cosmovisión que contienen los relatos orales, se logra construir una visión íntima y rica de la isla de Yunuén. Desde la creación de la isla, seres sobrenaturales que otorgan regalos, fantasmas arraigados a un lugar; pasando por festividades, rituales, costumbres. El rey que se ahogó es un desfile bellísimo de relatos que nos permiten construir toda una visión espacial, temporal y cultural de la isla de Yunuén. No hay 
que olvidar que, gracias a los coordinadores Santiago Cortés, Berenice Granados y colaboradores, pero, sobre todo, a los narradores, logramos recibir estas pequeñas joyas narrativas en nuestras manos.

Sandybell Rodríguez Juárez

(Facultad de Filosofía y Letras, UNAM)

hinata_kurosaki@outlook.com

ORCID: 0000-0001-7196-0437

9 